Jurnal Health Sains: p-ISSN: 2723-4339 e-ISSN: 2548-1398

Vol. 2, No. 5, Mei 2021

\title{
EVALUASI TINGKAT PENGETAHUAN MAHASISWA FARMASI UNIVERSITAS TADULAKO PALU MENGENAI OBAT GOLONGAN KORTIKOSTEROID
}

\section{Tirza Retno Kinasih Baginda, Amelia Rumi dan Yuliet}

Universitas Tadulako Sulawesi Tengah, Indonesia

Email: tirza.baginda@yahoo.com, amelia.rumi@gmail.com dan yuliet_susanto@yahoo.com

\begin{tabular}{l}
\hline ARTIKEL INFO \\
Tanggal diterima: 5 Mei 2021 \\
Tanggal revisi: 15 Mei 2021 \\
Tanggal yang disetujui: $25 \mathrm{Mei}$ \\
2021
\end{tabular}

Keywords:

corticosteroid; knowledge;

pharmacy students

\begin{abstract}
The knowledge level of pharmacy students about corticosteroid drugs is crucial since corticosteroid drugs have many dangerous side effects. This study aims to determine the knowledge level of the Faculty of Mathematics and Natural Sciences Pharmacy students at Tadulako University Palu regarding corticosteroid drugs and the factors that influence them. The study used a cross-sectional method using a questionnaire to 250 active students of the Faculty of Mathematics and Natural Sciences, Tadulako University Pharmacy study class 2017, 2018, and 2019. The sampling technique is purposive sampling. Descriptive data analysis used the chi-square test. The results showed that the knowledge level of pharmacy students about corticosteroid drugs showed that $36.4 \%$ of respondents had good knowledge, $31.6 \%$ had enough knowledge, and 32\% had insufficient knowledge. The results of statistical tests showed a significant relationship between the knowledge level and age with a batch of pharmacy students ( $p$-value <0.05). The conclusion is that Pharmacy students of the Faculty of Mathematics and Natural Sciences at Tadulako University have good knowledge regarding the dominant corticosteroid drugs and that the age and class of the students affect the knowledge level.
\end{abstract}

\begin{abstract}
ABSTRAK
Tingkat pengetahuan mahasiswa farmasi mengenai obat golongan kortikosteroid merupakan hal yang penting mengingat golongan kortikosteroid memiliki banyak efek samping berbahaya. Tujuan penelitian ini dalam rangka mengetahui tingkat pengetahuan dari mahasiswa Farmasi FMIPA Universitas Tadulako Palu mengenai obat golongan kortikosteroid dan faktor-faktor yang mempengaruhinya. Penelitian dilakukan dengan metode cross-sectional menggunakan kuesioner terhadap 250 mahasiswa aktif Prodi Farmasi FMIPA Universitas Tadulako angkatan 2017, 2018, dan 2019. Teknik pengambilan sampel menggunakan purposive sampling. Analisis data dilakukan dengan uji chi square dan disajikan secara deskriptif. Hasil penelitian menunjukkan tingkat pengetahuan mahasiswa farmasi mengenai obat golongan kortikosteroid menunjukkan
\end{abstract}

$\begin{array}{ll}\text { How to cite: } & \text { Baginda, Tirza Retno Kinasih, et. al (2021) Evaluasi Tingkat Pengetahuan Mahasiswa Farmasi } \\ & \text { Universitas Tadulako Palu Mengenai Obat Golongan Kortikosteroid. Jurnal Health Sains 2(5). } \\ & \text { https://doi.org/10.46799/jhs.v2i5.166 } \\ & 2723-6927 \\ \text { E-ISSN: } & \text { Ridwan Institute } \\ \text { Published by: } & \end{array}$


sebanyak 36,4\% responden berpengetahuan baik, 31,6\% berpengetahuan cukup dan $32 \%$ berpengetahuan kurang. Hasil dari uji statistik yaitu adanya suatu hubungan yang signifikan antara tingkat pengetahuan dengan umur dan angkatan mahasiswa farmasi ( $\mathrm{p}$ value $<0,05$ ). Kesimpulan penelitian ini yaitu tingkat pengetahuan mahasiswa Farmasi FMIPA Universitas Tadulako mengenai obat golongan

Kata Kunci:

kortikosterod; mahasiswa farmasi; pengetahuan kortikosteroid dominan berpengetahuan baik, dan tingkat pengetahuan dipengaruhi faktor umur dan angkatan mahasiswa.

\section{Pendahuluan}

Kortikosteroid merupakan sekelompok hormon steroid yang disekresi dan diproduksi oleh korteks kelenjar adrenal sebagai bentuk respon terhadap hormon adrenokortikotropik. Kelompok obat ini memiliki indikasi yang begitu luas dalam pengobatan sehingga disebut pula dengan istilah lifesaving drug (Kumala, 2018).

Obat golongan kortikosteroid memiliki manfaat yang luas. Namun di samping manfaat tersebut, terdapat efek samping berbahaya yang tidak boleh diabaikan. Efek samping berbahaya obat kortikosteroid disebabkan oleh penggunaan yang salah terhadap obat tersebut, salah satu pemicunya yaitu penggunaan berulang pada waktu yang relatif lama (Muslikah \& Susilowati, 2019). Efek samping juga dapat terjadi apabila terdapat penggunaan jangka panjang yang kemudian dihentikan secara mendadak (Siagian \& Maryanti, 2018).

Menurut (Paramsothy et al., 2017), penggunaan obat-obat ini harus terlebih dahulu mempertimbangkan antara besarnya manfaat pada pasien dibandingkan efek samping yang dapat ditimbulkan olehnya. Terlebih lagi pemberiannya pada pasien yang sudah memiliki penyakit penyerta. Penelitian (Sari, 2018) menunjukkan terdapat beberapa kasus efek samping seperti hipertrikosis, telangiekstasis dan dispigmentasi pada penggunaan kortikosteroid jangka panjang khususnya kortikosteroid topikal.
Berdasarkan penelitian (Yunita \& Wijayanti, 2017), penggunaan deksametason secara berulang dalam jangka waktu yang panjang dapat memicu efek samping berupa gangguan dan kerusakan pada organ pencernaan. Menurut Kumala \& (Widianingtyas, 2018), kurangnya pengetahuan individu akan penggunaan dan efek samping obat-obat golongan kortikosteroid yang menjadi pemicu timbulnya penggunaan yang salah dan tidak tepat yang kemudian berakar menjadi kemunculan efek samping yang tidak diinginkan. Hal ini didukung oleh penelitian (Muslikah \& Susilowati, 2019), yang menyatakan bahwa tingkat pengetahuan mengenai penggunaan obat golongan kortikosteroid secara signifikan dapat mempengaruhi ketepatan penggunaan obat tersebut.

Berdasarkan penelitian-penelitian yang telah dilakukan sebelumnya mengenai efek samping penggunaan obat-obat golongan kortikosteroid maka peneliti melakukan penelitian ini terhadap mahasiswa Jurusan Farmasi Universitas Tadulako untuk mengetahui tingkat pengetahuan mengenai obat golongan kortikosteroid dan faktorfaktor yang mempengaruhi tingkat pengetahuan tersebut.

\section{Metode Penelitian}

Penelitian telah dinyatakan layak untuk dilakukan dan sesuai dengan prinsip etika penelitian berdasarkan keputusan 
Komite Etik Penelitian Fakultas Kedokteran Universitas Tadulako Palu melalui Surat Pernyataan Komite Etik dengan nomor: 7785/UN.28.1.30/KL/2020

Penelitian ini memiliki desain observasional atau non-eksperimental. Penelitian dilakukan secara prospektif melalui pendekatan study cross-sectional dimana rancangan pengukurannya dilakukan oleh peneliti serentak pada waktu yang sama (Indra \& Cahyaningrum, 2019).

Penelitian ini dilakukan pada bulan September 2020 - Maret 2021 secara online berdasarkan lokasi pengisian kuesioner dari responden. Teknik pengambilan sampel secara purposive sampling, dimana sampel penelitian ini yaitu mahasiswa Jurusan Farmasi Universitas Tadulako Palu.

Teknik pengambilan data melalui pengisian kuesioner yang telah melalui uji validitas dan uji reliabilitas (Candra \& Yusuf, 2018), yang kemudian disebar menggunakan google form secara online melalui media sosial seperti WhatsApp, Facebook, dan Instagram. Uji validitas bertujuan untuk menilai alat ukur (dalam hal ini kuesioner) agar memiliki ketepatan dalam mengukur apa yang seharusnya diukur (Candra \& Yusuf, 2018). Sementara uji reliabilitas bertujuan menilai kepercayaan dan konsistensi suatu alat ukur untuk digunakan secara berulang (Syafril et al., 2020).

Data yang diperoleh kemudian dianalisis dengan uji Chi-square untuk melihat adanya hubungan antar variabel (Herlina, 2019) dan kemudian dianalisis secara deskriptif. Analisis dilakukan untuk melihat hubungan antar tingkat pengetahuan dengan umur, jenis kelamin dan angkatan mahasiswa. Kemudian mengetahui faktorfaktor yang mempengaruhinya.

\section{Hasil dan Pembahasan}

a. Uji Validitas dan Reliabilitas

Tabel 1

Hasil Uji Validitas

\begin{tabular}{|c|c|c|c|}
\hline Pernyataan & Nilai & $\begin{array}{c}\text { Nilai } \\
\text { r-tabel } \\
(\mathrm{a}=5 \%)\end{array}$ & Keterangan \\
\hline 1 & Korelasi & & Tidak Valid \\
\hline 2 & 0,252 & & Valid \\
\hline 3 & 0.378 & & Valid \\
\hline 4 & 0.528 & & Tidak Valid \\
\hline 5 & 0,322 & & Tidak Valid \\
\hline 6 & 0,269 & & Tidak Valid \\
\hline 7 & 0,275 & & Tidak Valid \\
\hline 8 & 0,198 & & Valid \\
\hline 9 & 0.560 & & Valid \\
\hline 10 & 0.335 & & Tidak Valid \\
\hline 11 & 0,054 & & Valid \\
\hline 12 & 0.592 & & Valid \\
\hline 13 & 0.349 & & Tidak Valid \\
\hline 14 & 0,026 & & Valid \\
\hline 15 & 0.642 & & Valid \\
\hline 16 & 0.505 & 0,325 & Tidak Valid \\
\hline 17 & 0,126 & & Valid \\
\hline 18 & 0.528 & & Tidak Valid \\
\hline 19 & 0,026 & & Tidak Valid \\
\hline 20 & 0,300 & & Valid \\
\hline 21 & 0.705 & & Valid \\
\hline 22 & 0.363 & & Valid \\
\hline 23 & 0.446 & & Valid \\
\hline 24 & 0.501 & & Tidak Valid \\
\hline 25 & 0,320 & & Tidak Valid \\
\hline 26 & 0,303 & & Tidak Valid \\
\hline 27 & $-0,021$ & & Valid \\
\hline 28 & 0.505 & & Valid \\
\hline 29 & 0.515 & & Valid \\
\hline 30 & 0.381 & & Valid \\
\hline 31 & 0,325 & & Tidak Valid \\
\hline 32 & 0,113 & & Valid \\
\hline
\end{tabular}

Pada uji validitas menggunakan aplikasi SPSS Versi 26. Uji validitas menggunakan 31 orang responden sehingga didapatkan nilai rtabel 0,325. Diperoleh sebanyak 18 pernyataan valid dari 32 pernyataan yang disebarkan. Penyataan dinyatakan valid apabila nilai rhitung > rtabel. 
Tabel 2

Hasil Uji Reliabilitas

\begin{tabular}{cc}
\hline Cronbach's Alpha & N of items \\
\hline 0,764 & 31 \\
\hline
\end{tabular}

Untuk uji reliabilitas menggunakan aplikasi SPSS Versi 26. Besar sampel sebanyak 31 orang responden diperoleh nilai Cronbach's Alpha 0,764. Kuesioner dinyatakan reliabel apabila nilai Cronbach's Alpha > 0,6.

b. Karakteristik Responden

\begin{tabular}{cccc}
\hline Variabel & Kategori & $\begin{array}{c}\text { Jumlah } \\
\text { Responden } \\
(\mathbf{n = 2 5 0 )}\end{array}$ & $\begin{array}{c}\text { Persentase } \\
(\boldsymbol{\%})\end{array}$ \\
\hline Umur & 18 & 11 & 4,4 \\
& 19 & 61 & 24,4 \\
& 21 & 94 & 37,6 \\
Total & 22 & 71 & 28,4 \\
Jenis & Laki-laki & 13 & 5,2 \\
\hline Kelamin & Perempuan & 210 & 100 \\
\hline Total & & 250 & 16 \\
Angkatan & 2017 & 92 & 100 \\
\hline Total & 2018 & 83 & 36,8 \\
\hline
\end{tabular}

Berdasarkan

karakteristik responden, dari total 250 orang responden, umur yang paling dominan mengisi kuesioner penelitian adalah umur 20 tahun sebanyak 94 orang responden $(37,6 \%)$. Kemudian berdasarkan jenis kelamin, responden yang paling dominan mengisi adalah yang berjenis kelamin perempuan sebanyak 210 orang responden (84\%). Lalu berdasarkan angkatan, yang dominan mengisi adalah angkatan 2017 sebanyak 92 orang responden $(36,8 \%)$.

c. Tingkat Pengetahuan dan Faktor yang Mempengaruhinya

Berdasarkan penelitian yang telah dilakukan terdapat 18 pernyataan pada kuesioner dan distribusi tingkat pengetahuan mahasiswa dapat dilihat sebagai berikut:
Tabel 4

Kategori Tingkat Pengetahuan

Mahasiswa Mengenai Obat Golongan Kortikosteroid

\begin{tabular}{ccccc}
\hline Kategori & $\begin{array}{c}\text { ata-rata } \\
\text { Skor }\end{array}$ & $\begin{array}{c}\text { Rata-rata } \\
\text { Persentase } \\
\text { Skor (\%) }\end{array}$ & $\begin{array}{c}\text { Jumlah } \\
\text { Responden } \\
\text { (Orang) }\end{array}$ & $\begin{array}{c}\text { Persentase } \\
\text { Responden }\end{array}$ \\
\hline Baik & 16 & 88,88 & 91 & 36,4 \\
\hline Cukup & 12 & 66,67 & 79 & 31,6 \\
\hline Kurang & 7,5 & 41,66 & 80 & 32 \\
\hline
\end{tabular}

Berdasarkan tabel 4, kategori tingkat pengetahuan mahasiswa yang paling dominan adalah yang berkategori baik, yaitu sebanyak 91 orang (36,4\%). Hal ini disebabkan oleh beberapa faktor yang dapat dilihat selanjutnya.

d. Hubungan Tingkat Pengetahuan dengan Umur

Berdasarkan penelitian yang dilakukan, diperoleh distribusi frekuensi tingkat pengetahuan berdasarkan umur (tabel 5) yang selanjutnya diuji chi square (tabel 6),

Tabel 5

Distribusi Frekuensi Tingkat

Pengetahuan Berdasarkan Umur

\begin{tabular}{|c|c|c|c|c|c|c|c|}
\hline \multicolumn{7}{|l|}{ Umur (tahun) } & \multirow[t]{2}{*}{ Tota } \\
\hline \multirow{4}{*}{$\begin{array}{l}\text { Pengetahuan } \\
\text { Obat }\end{array}$} & & 18 & 19 & 20 & 21 & 22 & \\
\hline & kurang & 7 & 17 & 17 & 16 & 0 & 57 \\
\hline & Cukup & 2 & 24 & 39 & 31 & 7 & 103 \\
\hline & Baik & 2 & 20 & 37 & 26 & 5 & 90 \\
\hline Tota & & 11 & 61 & 93 & 73 & 12 & 250 \\
\hline
\end{tabular}

Tabel 6

Hasil Uji Chi-Square Hubungan Umur dengan Tingkat Pengetahuan

\begin{tabular}{|c|c|c|c|c|}
\hline & & Value & Df & $\begin{array}{l}\text { Asymp. Sig. (2- } \\
\text { sided) }\end{array}$ \\
\hline $\begin{array}{l}\text { Pearson } \\
\text { Square }\end{array}$ & Chi- & $16.314^{\mathrm{a}}$ & 4 & 0.038 \\
\hline $\begin{array}{l}N \quad \text { of } \\
\text { Cases }\end{array}$ & Valid & 250 & & \\
\hline
\end{tabular}

Berdasarkan output di atas dapat diketahui bahwa nilai Asymp. Sig Pearson Chi-Square sebesar 0,038. Nilai Asymp. Sig $0,038<0,05$. Nilai ini menunjukan adanya suatu hubungan signifikan antara umur dan tingkat pengetahuan tentang 
obat golongan kortikosteroid. Hal ini dapat diartikan pula bahwa umur seseorang mempunyai korelasi atau hubungan dengan pengetahuan obat golongan kortikosteroid. Menurut (Murman, 2015), umur seseorang mempengaruhi kognisi seseorang yang artinya pemahaman dan pola pikir seseorang akan suatu pengetahuan ikut dipengaruhi dengan bertambahnya umur.

Berdasarkan tabel 5 terlihat bahwa semakin tinggi umur responden, maka semakin tinggi juga tingkat pengetahuannya. Menurut (Zulkarnain et al., 2020) pertambahan usia individu akan mempengaruhi berkembangnya konsep pemikiran individu tersebut. Terjadi perkembangan pada psikis seorang individu dimana progress pemikirannya berkembang secara bertahap menuju arah yang lebih sempurna seiring bertambahnya umur. Menurut (Simamora, 2019), umur seseorang mempengaruhi tingkat pengetahuan yang dimiliki seseorang. Hal ini diakibatkan oleh perkembangan daya tangkap dan pola pikir seseorang, sehingga semakin bertambah umurnya maka semakin baik pula pengetahuan yang diperoleh. Berdasarkan uji Chi Square yang telah dilakukan, terdapat hubungan antara umur dan tingkat pengetahuan mahasiswa Farmasi Universitas Tadulako, sehingga dapat dikatakan umur termasuk faktor yang turut mempengaruhi tingkat pengetahuan mahasiswa Farmasi Universitas Tadulako Palu mengenai obat golongan kortikosteroid.

e. Hubungan Tingkat Pengetahuan dengan Jenis Kelamin

Berdasarkan penelitian yang dilakukan, didapatkan hasil distribusi frekuensi tingkat pengetahuan mahasiswa berdasarkan jenis kelamin (tabel 7) yang selanjutnya melalui pengujian hubungan lewat chi square (tabel 8),
Tabel 7

Distribusi Frekuensi Tingkat

Pengetahuan Berdasarkan Jenis

Kelamin

\begin{tabular}{ccccc}
\hline \multirow{4}{*}{$\begin{array}{c}\text { Lenis Kelamin } \\
\text { Pengetahua } \\
\text { Obat }\end{array}$} & \multicolumn{3}{c}{ Perempuan } \\
\hline & & laki & Total \\
\cline { 2 - 5 } & Kurang & 9 & 48 & 57 \\
\cline { 2 - 5 } & Cukup & 15 & 88 & 103 \\
\cline { 2 - 5 } & Baik & 16 & 74 & 90 \\
\hline \multicolumn{2}{c}{ Total } & $\mathbf{4 0}$ & $\mathbf{2 1 0}$ & $\mathbf{2 5 0}$ \\
\hline
\end{tabular}

Tabel 8

Hasil Uji Chi-Square Hubungan Jenis Kelamin dengan Tingkat Pengetahuan

\begin{tabular}{|c|c|c|c|}
\hline & Value & $D f$ & $\begin{array}{c}\text { Asymp. Sig. } \\
\text { (2-sided) }\end{array}$ \\
\hline $\begin{array}{l}\text { Pearson } \\
\text { Chi-Square }\end{array}$ & 0,372 & 2 & 0.830 \\
\hline $\begin{array}{l}\text { Nof Valid } \\
\text { Cases }\end{array}$ & 250 & & \\
\hline
\end{tabular}

Berdasarkan output yang diperoleh, didapati nilai Asymp. Sig Pearson ChiSquare sebesar 0,830. Nilai Asymp. Sig $0,830>0,05$. Nilai ini menunjukan bahwa tidak ada hubungan antara jenis kelamin responden dengan tingkat pengetahuan mengenai obat golongan kortikosteroid.

Sehingga dapat diartikan bahwa jenis kelamin individu responden tidak memiliki hubungan (korelasi) dengan pengetahuan obat golongan kortikosteroid.

Berdasarkan tabel 7 terlihat bahwa pengetahuan baik lebih tinggi pada responden mahasiswa perempuan dibandingkan mahasiswa laki-laki.

Menurut (Salim et al., 2013), tingkat pengetahuan perempuan lebih baik dibandingkan laki-laki karena jiwa sosialisasi perempuan lebih tinggi dibandingkan dengan laki-laki, kecenderungan perempuan untuk sering bertukar pikiran dan lebih banyak berbicara juga mempengaruhi tingkat pengetahuan perempuan. Akan tetapi menurut penelitian (Wulandari et al., 
2016), jumlah responden perempuan yang lebih banyak dibandingkan dari laki-laki tentu menyebabkan pengetahuan perempuan lebih baik diakibatkan oleh kuantitasnya. Hal ini serupa dengan hasil dari penelitian ini dimana jumlah mahasiswa perempuan yang berkuliah di Prodi Farmasi Universitas Tadulako Palu jauh lebih banyak dibandingkan jumlah mahasiswa laki-lakinya yang mengakibatkan data jumlah responden mahasiswa perempuan yang memiliki tingkat pengetahuan yang baik jauh lebih banyak. Berdasarkan uji Chi Square yang telah dilakukan, tidak ada hubungan antara jenis kelamin dari mahasiswa dengan tingkat pengetahuan mahasiswa Farmasi Universitas Tadulako, sehingga jenis kelamin bukanlah faktor yang ikut mempengaruhi tingkat pengetahuan mengenai obat golongan kortikosteroid

f. Hubungan Tingkat Pengetahuan dengan Angkatan

Berdasarkan penelitian yang dilakukan, didapati hasil distribusi frekuensi tingkat pengetahuan berdasarkan angkatan (tabel 9) yang selanjutnya melalui pengujian hubungandengan uji chi square (tabel 10),

Tabel 9

Distribusi Frekuensi Tingkat

Pengetahuan Berdasarkan Angkatan

\begin{tabular}{|c|c|c|c|c|c|}
\hline \multicolumn{5}{|c|}{ Angkatan } & \multirow[t]{2}{*}{ Total } \\
\hline \multirow{4}{*}{$\begin{array}{c}\text { Pengetahuan } \\
\text { obat }\end{array}$} & & 2017 & 2018 & 2019 & \\
\hline & Kurang & 18 & 14 & 25 & 57 \\
\hline & Cukup & 41 & 31 & 31 & 103 \\
\hline & baik & 34 & 37 & 19 & 90 \\
\hline \multicolumn{2}{|c|}{ Total } & 93 & 82 & 75 & 250 \\
\hline
\end{tabular}

Tabel 10

Hasil Uji Chi-Square Hubungan Angkatan dengan Tingkat Pengetahuan

\begin{tabular}{|c|c|c|c|}
\hline & Value & $D f$ & $\begin{array}{l}\text { Asymp. Sig. } \\
\text { (2-sided) }\end{array}$ \\
\hline $\begin{array}{l}\text { Pearson Chi- } \\
\text { Square }\end{array}$ & $10.005^{\mathrm{a}}$ & 4 & 0.040 \\
\hline $\begin{array}{l}N \text { of Valid } \\
\text { Cases }\end{array}$ & 250 & & \\
\hline
\end{tabular}

Berdasarkan output yang diperoleh setelah di uji Chi square dapat diketahui bahwa nilai Asymp. Sig Pearson ChiSquare sebesar 0,040. Nilai Asymp. Sig $0,040<0,05$. Nilai ini menunjukan adanya hubungan signifikan antara angkatan dari responden dengan pengetahuan responden mengenai obat golongan kortikosteroid. Hal ini sesuai dengan penelitian tingkat pengetahuan mahasiswa yang pernah dilakukan sebelumnya, dimana tinggi tingkat semester mahasiswa dapat mempengaruhi tingkat pengetahuan dari mahasiswa (Wulandari et al., 2016). Sehingga, dapat dilihat bahwa angkatan seseorang mempunyai korelasi atau hubungan dengan pengetahuan obat golongan kortikosteroid.

Berdasarkan tabel 9 dapat dilihat bahwa angkatan mahasiswa menjadi salah satu faktor yang ternyata ikut mempengaruhi dalam tingkat pengetahuan dari mahasiswa mengenai obat golongan kortikosteroid. Pada data yang diperoleh, jumlah mahasiswa yang memiliki pengetahuan baik tertinggi ada pada angkatan 2018, selanjutnya angkatan 2017, terakhir angkatan 2019. Hal ini tidak sesuai dengan penelitian (Wulandari et al., 2016), dimana seharusnya semakin tinggi semester, maka semakin tinggi pula tingkat pengetahuan mahasiswa. Pada penelitian (Astiani \& Pertiwi, 2019), tinggi angkatan mempengaruhi tingkat pengetahuan mahasiswa, semakin tinggi angkatannya maka seharusnya semakin tinggi juga tingkat pengetahuannya. Sebab semakin tinggi angkatan, semakin tinggi semester mahasiswa tersebut. Berdasarkan uji Chi Square yang telah dilakukan, ada hubungan antara angkatan dan tingkat pengetahuan, sehingga angkatan menjadi faktor yang ikut membawa pengaruh pada tingkat pengetahuan mahasiswa Farmasi Universitas Tadulako. Disamping itu, 
ketidaksesuaian data bisa terjadi akibat faktor lainnya. Salah satu faktor adalah materi pembelajaran pada semester yang sementara dilalui oleh mahasiswa, bisa jadi materi mengenai golongan Kortikosteroid banyak dibahas pada mata kuliah angkatan 2018 yang sementara berjalan, seperti mata kuliah Farmakoterapi 1 dan Farmakoterapi 2, mata kuliah Spesialite Obat dan Alkes, Farmakologi Toksikologi dan lain-lain, sehingga mempengaruhi tingkat pengetahuan mahasiswa pada saat menjadi responden penelitian.

\section{Kesimpulan}

Kesimpulan penelitian ini yaitu tingkat pengetahuan yang dominan yaitu pada pengetahuan baik, dimana terdapat $36,4 \%$ mahasiswa berpengetahuan baik, lalu 31,6\% berpengetahuan cukup dan $32 \%$ berpengetahuan kurang. Faktor-faktor yang mempengaruhi tingkat pengetahuan ini yaitu umur dan angkatan dari mahasiswa. Untuk hasil yang lebih baik, diperlukan adanya penelitian lanjutan dengan cakupan ruang lingkup yang lebih luas dan jumlah respondennya lebih banyak pula.

\section{BIBLIOGRAFI}

Astiani, R., \& Pertiwi, I. (2019). Pengetahuan Mahasiswa S1 Farmasi Universitas 17 Agustus 1945 Terhadap Cara Penggunaan Antibiotik Knowledge Of Student Pharmaceuticals On Antibioic Use. Google Scholar

Candra, A. I., \& Yusuf, A. (2018). Studi Analisis Daya Dukung Pondasi Tiang Pada Pembangunan Gedung Lp3m Universitas Kadiri. Jurnal Civila, 3(2), 166-171. Google Scholar

Herlina, V. (2019). Panduan Praktis Mengolah Data Kuesioner Menggunakan Spss. Elex Media Komputindo. Google Scholar
Indra, I. M., \& Cahyaningrum, I. (2019). Cara Mudah Memahami Metodologi Penelitian. Deepublish: Sleman. Google Scholar

Kumala, A. P. (2018). Evaluasi Penggunaan Obat Kortikosteroid Di Apotek Hs 23 Periode Februari-April 2018. Jurnal Kefarmasian Akfarindo, 7-12. Google Scholar

Murman, D. L. (2015). The Impact Of Age On Cognition. Seminars In Hearing, 36(3), 111. Google Scholar

Muslikah, N., \& Susilowati, E. (2019). Pengaruh Tingkat Pengetahuan Terhadap Ketepatan Penggunaan Obat Kortikosteroid Secara Swamedikasi Pada Masyarakat Yang Berkunjung Di Apotek X Kota Malang. Akademi Farmasi Putra Indonesia Malang. Google Scholar

Paramsothy, S., Kamm, M. A., Kaakoush, N. O., Walsh, A. J., Van Den Bogaerde, J., Samuel, D., Leong, R. W. L., Connor, S., Ng, W., \& Paramsothy, R. (2017). Multidonor Intensive Faecal Microbiota Transplantation For Active Ulcerative Colitis: A Randomised PlaceboControlled Trial. The Lancet, 389(10075), 1218-1228. Google Scholar

Salim, S., Alatas, S., \& Linuwih, S. (2013). Hubungan Tingkat Pengetahuan Mengenai Pedikulosis Kapitis Dengan Karakteristik Demografi Santri Pesantren X. Jakarta Timur: Fakultas Kedokteran Universitas Indonesia. Skripsi. Google Scholar

Sari, F. (2018). Metode Dalam Pengambilan Keputusan. Deepublish. Google Scholar

Siagian, F. E., \& Maryanti, E. (2018). EReading Vs Traditional Reading: Can Internet, Social Media And Gadgets Bridge The Gap Between Reading And Learning Among Medical Students? 
Jurnal Ilmu Kedokteran, 11(2), 52-59. Google Scholar

Simamora, R. H. (2019). Pengaruh Penyuluhan Identifikasi Pasien Dengan Menggunakan Media Audiovisual Terhadap Pengetahuan Pasien Rawat Inap. Jurnal Keperawatan Silampari, 3(1), 342-351. Google Scholar

Syafril, S., Yaumas, N. E., Ishak, N. M., Yusof, R., Jaafar, A., Yunus, M. M., \& Sugiharta, I. (2020). Characteristics And Educational Needs Of Gifted Young Scientists: A Focus Group Study. Journal For The Education Of Gifted Young Scientists, 8(2), 947-954. Google Scholar

Widianingtyas, N. (2018). An Experimental Research of Contextualized And Decontextualized Methods In Fostering Students'vocabulary Retention. Sanata Dharma University. Google Scholar
Wulandari, P., Putri, N. I. S., Kassim, S., \& Sulung, L. A. (2016). Contract Agreement Model For Murabahah Financing In Indonesia Islamic Banking. International Journal of Islamic And Middle Eastern Finance And Management. Google Scholar

Yunita, D., \& Wijayanti, A. (2017). Pengaruh Media Video Pembelajaran Terhadap Hasil Belajar Ipa Ditinjau Dari Keaktifan Siswa. Sosiohumaniora: Jurnal Ilmiah Ilmu Sosial Dan Humaniora, 3(2). Google Scholar

Zulkarnain, Z., Redjeki, E. S., Raharjo, K. M., \& Wahyuni, S. (2020). Pemberdayaan Anak Jalanan Dalam Pengembangan Kewirausahaan Binaan Pondok Pesantren Sabilul Hikmah Malang. Abdimas Pedagogi: Jurnal Ilmiah Pengabdian Kepada Masyarakat, 3(1), 59-68. Google Scholar

\section{Copyright holder:}

Tirza Retno Kinasih Baginda, Amelia Rumi dan Yuliet (2021)

First publication right:

Jurnal Health Sains

This article is licensed under:

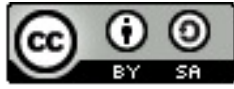

